\title{
Sustainable Natural Resources and
}

\section{Environmental Management Systems: Approach of Green Leadership Model}

\author{
Normalina $^{1}$, Muhammad Hatta ${ }^{2}$, Hafizianoor ${ }^{3}$, Hamdani $^{4}$ \\ ${ }^{1}$ Doctoral Program, Faculty of Agriculture Science, State \\ University of Banjarbaru, Indonesia, \\ ${ }^{2,3,4}$ University of LambungMangkurat, South Kalimantan, Indonesia
}

Received: November 16, 2020. Revised: April 22, 2021. Accepted: May 13, 2021. Published: May 17, 2021.

\begin{abstract}
The research method is qualitative with a theory research action combination with phenomenological approach. The research design using multi-site involving six locus in South Kalimantan, Indonesia. Data collection techniques used were content analysis, participatory observation and depth interviews. The analysis used in answering this research is a combination of various analytical methods to answer each of the objectives namely miles \& Huberman analysis, BAPenas MAPP Analysis, Siagian Leadership Role Analysis and Webbed Spider Model Analysis as the ultimate in formulating green leadership models in the management of natural resources and sustainable environment. This study aims to observe, study and find events related to the focus of research to get the formulation of a model of green leadership in the management of natural resources and the sustainable environment that appears naturally. The results of this research found that the Green Leadership Model's has the criteria : has an understanding of environmental issues, response to policies, community accessibility, institutional support, commitment to environmental sustainability, has innovation that is pro to the environment and an optimal role for leaders in the management of natural resources and sustainable environment. These included the following; in the past experience, sustainable management of natural resources and the environment around the Meratus mountains is strongly influenced by the leadership role both formally and informally. Sustainability of natural resource management and sustainable environment is strongly influenced by leadership who: has awareness and love for the environment, provide motivation through direct implementation to the community through policies that are implemented in maintaining environmental sustainability, provide broad access for the community to participate in the management of natural resources and the environment
\end{abstract}

which experiences a lot of quality degradation ; firm and able to refuse in responding to the demands of the business world which focus on increasing profits alone to exploit natural resources and the environment; and has criteria as an environmentally friendly leadership model in accordance with the criteria needed as an ideal description of leadership. Green leadership models in the management of natural resources and the environment come from formal and informal leadership. The formal green leadership comes from the Regional / Institution / Institution of government, while the informal green leadership comes from the customary leadership that carries out customary rules that do not conflict with government regulations in the management of natural resources and the sustainable environment.

Key words: Sustainable, Natural resources, environmental system, Green, Model

\section{INTRODUCTION}

In South Kalimantan, the flood disaster is an ecological disaster due to the mismanagement of its environmental areas. Walhi of South Kalimantan said that currently in the South Kalimantan region of 3.7 hectares, $50 \%$ has been burdened with mining permits and oil palm plantations, not including Industrial Plantation Forest/HTI and Forest Concession Rights/HPH. The damaged and critical land cover and watershed as well as weak law enforcement for perpetrators of environmental crimes against rogue corporations that exploiting natural resources and the environment solely for profit purposes. Environmental damage in South Kalimantan includes: environmental degradation especially; an increase in forest damage, a decrease in the number of protected forests, watershed damage, poor/low waste management, an increasingly high level of pollution, forest fires that have an impact on disruption of local transportation activities, and the decreasing number of trees in South Kalimantan due to the development of the housing, mining and industry that continues to grow without regard to the requirements and 
concerns for the management of natural resources and sustainable environment in South Kalimantan.

The results of the latest critical land review conducted by the Central Kalimantan Watershed and Protected Forest Management Agency/ South Kalimantan Province Watershed and Protected Forest Management Center stated that in 2018 the area of degraded land in South Kalimantan Province still reached 511.594 ha, although this figure is decline from the review data in 2014 which mentioned the critical land in South Kalimantan province which reaches an area of 640.708 hectares, with details inside a forest area of $283.185,00$ ha $( \pm$ $44.20 \%)$ and outside a forest area of $357.523,00$ ha ( \pm $55.80 \%$ ), (performance report of the forestry office in 2019). The fastest way to be able to overcome all environmental problems is to optimize the role of leaders who are pro towards the management of natural resources and sustainable environment. The question is what kind of leadership that able to answer these environmental problems?. In line with this, based on environmental theory, a leader must be able to change the model and style of leadership in accordance with the demands and situations of the times. Therefore, changing circumstances and conditions require changing styles and models of leadership. Because, if the leader does not make changes in accordance with the needs of the times, his/her leadership will not succeed optimally. The purpose of this research is to observe and study the events related to the focus of research to get the formulation of a model of green leadership in the management of natural resources and the sustainable environment that appears naturally.

\section{Literature Review}

Green innovation is a type of innovation that not only can have benefits for consumers and enterprises but also can greatly decrease the adverse effects on the environment [1][4]. It includes the technique innovation involving in energy saving, pollution prevention, waste recycling, design for green products, environmental management so forth [5]-[7]. As an integral part of green innovation, green technology innovation has received continuous attention because of the growing concern over the state of the environment [8]. Characteristics of the systems to be integrated: Given the inter-dependencies between social and ecological systems, a detailed understanding of each is essential for further improvements on their integration and sustainability achievements. The social system refers to all human-related aspects that influence or are influenced by the "issue of concern," and may include different sectors of economy, politics, and technology. These aspects depend on human behavior towards all services provided by the natural system. [9]. Characterizing the role of Earth and environmental science in addressing SDGs (individual exercise). (a) Participants reflected on which of the 17 SDGs would most benefit from greater understanding of Earth and environmental science. Each workshop included short talks to set context, and ensure common understanding of 'Earth and environmental science' by participants with diverse backgrounds. Each individual participant had four voting stickers to place on the 17 SDG posters that they considered to have a high requirement for Earth and environmental science research. (b) In Zambia and Tanzania, participants added notes on specific ways in which Earth and environmental science can support the delivery of the SDGs. [10]. In the same way,[11] have extended the theory of planned behavior by showing that green consumer behavior is influenced by not only a person's behavioral intention to visit green hotels, but also by his decisions regarding personal choices such as "Which green hotel should I visit?" and "How much will I pay for a green hotel?" Social environmentalism intends to capture the power of con- sumers' beliefs about their society's role in protecting the environment by adopting environmentally conscious behaviors. Such belief is usu- ally inspired by consistent feelings, tendencies and evaluations with regard to environmental activities (e.g., increases in environmental damage) [12]-[14]. Therefore, these can motivate an empirical assessment of hotel visitors' behavior. [11]. Human needs are not only material needs, mental, intellectual and spiritual. Human needs run simultaneously or concurrently to the different levels of [15].

The methods used to study relationships between place and health greatly shape the foundation of knowledge that exists in this field. Our approach separately compared group-level associations, and individual within-person effects, of green space on walking and cycling, leveraging longitudinal data to strengthen the basis for causal inference. Our results indicate that walking, and particularly leisure walking, decreases as green spaces are moved further from one's residence. However, local green space alone may not significantly affect physical activity. Replicating our approach on larger, diverse study samples with more variability across time would strengthen the reliability of these findings, or introduce different patterns of effect. [16]. Crisis leadership denotes a set of actions undertaken by a leader to bring about immediate change in people's behavior and beliefs as well as to achieve needed outcomes [17]-[19]. In a crisis situation, a leader provides "stability, reassurance, confidence, and a sense of control" [20]

[21] argue that leaders in crisis situations are under severe time pressure and lack the time to effectively acquire, secure, and process information [20]. Transformational leadership emphasizes inspiration, motivation, challenge, vision, personal development and superior performance by followers. There is also considerable evidence that transformational leadership is effective, and it is positively related to subordinate satisfaction, motivation, and performance [22]. As to the transactional approach, it makes a strong link between leadership and the ability to motivate goal attainment and improved performance through reward structures [23]. The aim of this research is to investigate the influence of the locus of control and that of the decision-making capacity upon the leadership style (orientation towards tasks versus orientation towards human relations) [24].

\section{MATERIAL AND METHOD}

This research uses a qualitative approach. The design of this study uses the multi-site research that is a qualitative research design in the form of a field research design (field study), which aims to study the location of research that is in reasonable conditions, This research is a combination of case study and action research, so that the resulting research is really based on facts and real actions that occur in the field 
without any manipulation of the action as the basis for drawing conclusions.

In this qualitative study, the researcher as the main tool for conducting data collection is the most strategic step in research, because the main objective of the research is to obtain data. Data collection can be done in a variety of settings, sources, and ways. When viewed from its settings, data can be collected in natural settings. The selection of research subjects uses criterion-based selection (Muhadjir, 1993), which is based on the assumption that the subject is an actor in the proposed research theme. In addition, in the determination of the informant can be used the snowball sampling model. This method is used to expand the subject of research. The selection of informants is conducted purposively / the purposive sampling technique is used to direct the collection of data according to needs through the selection of informants who really master the information and research problems in depth and can be trusted to be a reliable source of data. The main data sources in qualitative research are words, and action the rest are additional data such as documents, observations and others.

This study uses a multi-site study, involving 6 sites and several research subjects, namely the Provincial Government of South Kalimantan, Banjarmasin City, Banjarbaru City, Hulu Sungai Selatan Regency, Hulu Sungai Tengah Regency and Tanah Bumbu Regency, and does not rule out adjusting to the research needs with locations in the regencies/cities in South Kalimantan that are relevant in this study.

The study was conducted using qualitative methods in data collection in the form of interviews, participant observation and document analysis. The interview used is an unstandardized interview conducted without compiling a strict list of questions. Furthermore, this unstandardized interview was developed in three techniques, namely: 1) unstructured interview (passive interview), 2) somewhat structured interview (somewhat structured interview or active interview) and 3) casual interview.

\section{Deep interview}

[25] state that the in-depth interview technique is a typical data collection technique for qualitative research. [26]-[28] states that in-depth interviews in qualitative research which are stated by many literatures in various terms: intensive interviewing, in-depth interviewing or unstructured interviewing is a focused conversation whose purpose is to collect or enrich very detailed information or materials (data). rich and solid which the end result is used for qualitative analysis.

Participant observation is a characteristic of social interaction between researchers and research subjects. In other words, it is the process for the researcher to enter the setting in order to observe how the events in the setting relate to one another.

\section{Documentation}

In this qualitative research, data collection in the form of documents was carried out. Various types of information can be obtained through documentation such as: official letters, meeting notes, reports, clipping media articles, proposals, agendas, memoranda, progress reports that are considered relevant to the researcher being worked [29]-[32]. Documents and records can provide very valuable information, besides their availability can be obtained at a relatively lower cost [25]. Documents can also reflect a rather precise situation and can be analyzed again and again without fear of change. Documents and records are contextually rich sources of information,

The method of observation carried out is by seeing and hearing the events or actions of people observed and then record the results of their observations with notes or other assistance. Researchers are the main research instruments that must be present directly in the field to collect and conduct data analysis.

The data in this study consisted of human data sources and non-human data sources. Human data sources are people who know or are experts on the issues discussed in this study, while non-human data sources are various documents in the form of planning, implementing and evaluating documents in the management of natural resources and sustainable environment.

Research design is a strategy chosen by researchers to thoroughly integrate research components in a logical and systematic way to discuss and analyze what becomes the focus of research. This research observes and examines events related to the focus of research to get the formulation of a model of green leadership in the management of natural resources and the sustainable environment that appears naturally. In this study data collection is not using quantitative tests or questionnaires; the priority is the response that can be quantified so that it can be processed statistically, while those who deviate from it are ignored.

The analysis used in answering this research is a combination of various analytical methods to answer each of the objectives in obtaining findings related to formulating green leadership models in the management of natural resource and the environment in South Kalimantan, namely miles \& Huberman analysis, MAPP Bapenas Analysis, Siagian Leadership Roles Analysis and Analysis of the Webbed Spider Model. Details and explanations about data collection and key informants are shown in Table 1.

\section{RESULTS AND DISCUSSION}

The findings of the green leadership research model in the management of natural resources and the sustainable environment consist of two domains, namely: 1) on an informal level, based on interviews with the damang (Customary/Adat Leaders of the Dayak Meratus tribe), natural resource management and the environment are always oriented on local wisdom in its implementation, growing and maintaining a positive sense of belonging on the natural resources and the environment so that they really maintain from the potential damage, the obedience of indigenous peoples in complying with customary rules and government rules consistently, the ability of customary/adat leaders to deliver government regulations that are juxtaposed with customary rules to the community so that they are able to walk side by side in harmony, the understanding and ability of indigenous/customary leaders to predict potential problems that will arise from an action on natural resources and the environment, having knowledge and understanding of the functions and benefits of natural resources and the 
environment in a sustainable manner, having an unlimited and very strong love for natural resources and environment based on the order of customary values that are upheld by indigenous

peoples, has the ability to influence the community and is chosen voluntarily by the community itself, while 2) green leadership at the Formal level based on the results of document analysis, content analysis, participant observation and in-depth interviews with informants from formal leaders (elements of government), the green leadership model is leadership that has a concern and strong response to environmental issues in the management of natural resources and sustainable environment, able to read rules that can be juxtaposed with customary rules that apply in indigenous communities for generations based on local wisdom in their implementation, able to facilitate and communicate the role and contribution of the community with the government through their involvement in the management of natural resources and sustainable environment, have a commitment to keep-maintain-preserve natural resources and the environment as noble values from God as a gift that must be preserved and maintained its existence, has innovations that are able to facilitate in maintaining and minimizing damage to the natural resources and sustainable environment, carry out the function and role of the leader as a whole in the process of planning, implementation and supervision in the management of natural resources and sustainable environmental, full support of formal institutions through the authority possessed as a leader in creating, determining and implementing management functions in the management of natural resources and the sustainable environment legally.

Finally, it can be concluded that the results of this study are in the form of a green leadership model that has the following criteria: green leadership has an understanding of environmental issues, response to policies, community accessibility, institutional support, commitment to environmental sustainability, has innovations that are proenvironment and the optimal role of the leader in the management of natural resources and sustainable environment. The formulation is based on research findings that are combined and narrated simply.

Table 2. Research Informants

\begin{tabular}{lcccc}
\hline & Informant1 & Informant2 & Informant 3 & Tot: \\
\hline Locus 1 & Leader & NGO & $\begin{array}{c}\text { College } \\
\text { Practitioners }\end{array}$ & 3 \\
Locus 2 & Leader & NGO & $\begin{array}{c}\text { College } \\
\text { Practitioners }\end{array}$ & 3 \\
Locus 3 & Leader & Figure & Community & 3 \\
Locus 4 & Leader & Figure & Community & 3 \\
Locus 5 & Leader & Figure & Community & 3 \\
Locus 6 & Leader & SKPD & DPRD & 3 \\
\hline Total & 6 & $2 / 3 / 1$ & $2 / 5 / 1$ & 18 \\
\hline
\end{tabular}

Table 3. Provincial and regency / city locus area in 2019.

\begin{tabular}{lcc}
\hline $\begin{array}{l}\text { Regency / City } \\
\text { Name }\end{array}$ & $\begin{array}{c}\text { Total } \\
\text { Area } \\
\left(\mathbf{k m}^{2}\right)\end{array}$ & $\begin{array}{c}\text { Percentage towards } \\
\text { province area }\end{array}$ \\
\hline \multicolumn{1}{c}{$(1)$} & $(2)$ & $(3)$ \\
South Kalimantan & $38.744,23$ & 100 \\
Banjarmasin & 371,00 & 0.96 \\
Banjarbaru Sungai & 72,00 & 0.19 \\
Hulu & 1804,94 & 4,66 \\
Selatan Sungai & 1472,00 & 3,80 \\
Hulu & & \\
Tengah & 5006,96 & 12,92 \\
Tanah Bumbu & & \\
\hline
\end{tabular}

Source. BPS, 2020

Provincial Government of South Kalimantan, the reason for choosing this locus represents the highest leadership of the South Kalimantan province who has full authority in the power to make the highest regulations/policies in the region and has a comprehensive impact in order to mobilize the regency/ city as a whole in implementing the policy in the regency/city, however stay focused in the management of the natural resources and sustainable environmental. This is realized through the important role of setting and implementing policies that are environmentally oriented and oriented towards local wisdom, which is carried out by the South Kalimantan provincial forestry and environment office.

Management of natural resources that is not in accordance with the principles of sustainable development will have impacts such as the preservation of natural resources being threatened, environmental damage and pollution, such as water, air and land pollution, and inter-generational gaps. Sustainable development is a development process (land, cities, businesses, communities, etc.) with the principle of "meeting the needs of the present without sacrificing the needs of future generations, with an emphasis on the carrying capacity of the environment, the achievement of social justice, economic and environmental sustainability.

The condition of sustainable natural resource management and the environment in South Kalimantan is translated in the form of Regional Regulation no. 7 of 2016, which is formulated with due regard to strategic issues of sustainable development. The province's strategic sustainable development issues are contained in 13 priorities, 168 programs, and 238 indicators .

Forestry sector form Conservation and Sustainable Use of Land Ecosystems, The main issues are forestry management, conservation and biodiversity, preserving and utilizing the economic value of living, law enforcement in the environmental sector, animal and plant quarantine, and animal and vegetable biosafety. Forestry governance performance enhancement is carried out through the establishment and operation of FMUs. In this field, social forestry is able to make a very large contribution to increasing the income of the people living around the forest. Through the Green Revolution program launched by the provincial government of South 
Kalimantan, namely the massive tree planting movement that aims to reduce critical land areas, restore watersheds and empower communities. The green revolution has succeeded in reducing the area of critical land in South Kalimantan from 649,000 hectares to 511.000 hectares in the last three years. The concept of the green revolution itself is how to create forests and the potential in them to prosper the community by prioritizing environmental preservation.

The green revolution is one of the main achievements of the successful development of the forestry sector in South Kalimantan. Through this green revolution movement, South Kalimantan has succeeded in increasing the Environmental Quality Index (IKLH) of South Kalimantan province in a sustainable manner and has become a model for other provinces. The Provincial Government of South Kalimantan is targeting the restoration of the damaged forest and land areas as an effort to make the area one of the lungs of the world. Every year tree planting activities carried out by the government, private sector and the community reach more than 35 thousand hectares.

Banjarmasin city government, as a locus of research that is able in the past five years to maintain local wisdom (optimization and management of river functions; as a tourist and trade area, river bank management) and show the application of policies that are concerned with the management of natural resources and the sustainable environment, especially in waste management through reducing the use of shopping plastic bags.

Banjarbaru City Government, Mayor of Banjarbaru (Urban arrangement that is environmentally friendly): Banjarbaru with character and Smart City was chosen as the locus of research because in the last five years has been focus and been able to make an urban arrangement that is environmentally friendly, child friendly and optimally empowering communities, in an effort to manage natural resources and sustainable environment in South Kalimantan, through the thematic village program as a form of local community empowerment.

Upper South River Regency Government, as one of the regencies that is able to maintain the green area in the meratus mountain region, the existence of a protected area which is a source of life for its people without damage, an area that is still able to maintain the existence of protected forests and is able to foster love and involve the community in the management of natural resources and the sustainable environment. Having a traditional leader (Damang) who has a very strong role and influence of leadership in the management of the natural resources and sustainable environment based on the rules and without breaking the rules that have been set by the government.

Hulu Tengah Regency Government, is a regency that still maintains a green GRDP and maintains development that does not exploit the environment. Able to influence the community from customary stakeholders, community leaders such as Dayak meratus traditional leaders and strong local wisdom concepts.

Land Bumbu Regency Government, is a regency that has received an award as a climate village from the ministry of environment and forestry in 2019, was chosen as a locus of research even though the management of natural resources and the environment (which is a mining area has been able to show positive assumptions because it is able to improve, organize and reduce the impact of global warming: post mining; responsible reclamation is represented by PT.Tunas Inti Abadi mining company that is able to manage the post-mining condition to turn green again, and PT. Arutmin Indonesia through the Climate Village Program), which is able to make the area as a responsible mining Area as a national example, and has a strong determination in the management of natural resources and sustainable environment from different sides because of different environmental biophysics as well.

The main points that can be captured from the results of this discussion are :

1. Green leadership understands and responds to the issue of the management of natural resources and sustainable environment.

2. Green leadership response and commitment in making priority policies in the management of natural resources and sustainable environment.

3. Green leadership provides easy accessibility and widely opens space for community participation in the management of natural resources and sustainable environment.

4. Green leadership optimizes leadership roles in the management of natural resources and the sustainable environment.

5. Green leadership is formal and informal leaders who have the ability to influence in different ways in the management of natural resources and sustainable environment.

6. The formulation of the green leadership model (green leadership) is able to improve the better implementation in the management of natural resources and sustainable environment.

\section{CONCLUSION}

Based on the discussion of research results, it can be concluded that green leadership is very important and highly needed because it is able to answer the world's needs to maintain and sustain the sustainability of natural resources and sustainable environment as a source of livelihood and life of the community at large. The local wisdom-based approach is an implementation of Green Leadership, which is the ability of a person (leader) to influence others to do something based on a strong commitment to keeping the environment sustainable and having a holistic love for the environment through the cultivation of values and good examples. includes the constituent elements of green leadership as a form of approach that must be taken, namely:

1. Have a strong understanding of environmental issues in the area / in the vicinity with the ability to answer $4 \mathrm{~W} 1 \mathrm{H}$ questions with heart related to issues of sustainable natural resource and environmental management. have high sensitivity and concern in looking at the potential for environmental problems.

2. Have a smart response to policy created, and or applied in the management of natural resources and the environment in a sustainable manner. Able to analyze the right regulations to be implemented in the community by 
paying attention to the legal basis, needs and friendliness of the regulations that are compiled and applied.

3. Providing accessibility to the community to play the widest possible role in engaging in the management of natural resources and the environment in a sustainable manner, either directly or indirectly. The general public has broad access to the management of natural resources (which can be renewed) and the environment in a sustainable manner. Benefit from natural resource management (which cannot be renewed) proportionally as a community.

4. Having a solution in the form of innovation which can be implemented, imitated, adopted, adapted and modified which provide broad benefits to increasing the welfare and happiness of society. Innovation does not only come from leaders at the formal level, but it does not rule out the possibility that these innovations can emerge from the community itself. The increasingly creative way of thinking of the community can lead to the development of thematic villages as examples of simple innovations that provide high economic value for improving the welfare of the community. Innovation in the form of appropriate technology that meets 4 eligibility requirements.

5. Institutions a forum that is able to accommodate community complaints regarding the environment, providing solutions to community complaints regarding sustainable natural resource management and the environment. Institutions have formal authority as a leader in designing policies / regulations that are pro to the environment, proposing a budget that is proportional to the strategic steps of the vision-mission and the RPJMD which prioritize environmentally sustainable development.

6. Green leaderships a strong commitment of a leader in managing natural resources and the environment in a sustainable manner through a value approach and his ability to mobilize and change the people's mindset to love the environment more through a religious approach. Green Leadership is leadership that is able to answer challenges / problems from environmental issues that occur from various aspects. the approach taken by green leadership does not only come from formal leadership but also from traditional (non-formal) leadership

\section{ACKNOWLEDGMENT}

Thank you to the author to promoters and co-promoters who had guided this research into starting breastfeeding proposals to research reports.

\section{REFERENCES}

[1] M. Dangi, A. Ismail, R. Johari, and R. Noor, "SME's Internationalization Initiatives: Business \& Growth Strategy ICT and Technology," Int. J. Accounting, Financ ..., no. Query date: 2021-02-01 17:55:11, 2018, [Online]. Available: http://www.ijafb.com/PDF/IJAFB2018-12-06-07.pdf.

[2] Y. Zhang, C. Xing, and Y. Wang, "Does green innovation mitigate financing constraints? Evidence from China's private enterprises," Journal of Cleaner Production, vol. 264, p. 121698, 2020.

[3] L. Qiu, X. Jie, Y. Wang, and M. Zhao, "Green product innovation, green dynamic capability, and competitive advantage: Evidence from Chinese manufacturing enterprises," Corporate Social Responsibility and Environmental Management, vol. 27, no. 1, pp. 146165, 2020.

[4] M. Wang, Y. Li, Z. Cheng, C. Zhong, and W. Ma, "Evolution and equilibrium of a green technological innovation system: Simulation of a tripartite game model," Journal of Cleaner Production, vol. 278, p. 123944, 2021.

[5] S. Scarpellini, J. Valero-Gil, J. M. Moneva, and M. Andreaus, "Environmental management capabilities for a 'circular eco-innovation," Business Strategy and the Environment, vol. 29, no. 5, pp. 1850-1864, 2020.

[6] C. Lee and S.-Y. Lim, "Impact of environmental concern on Image of Internal GSCM practices and consumer purchasing behavior," The Journal of Asian Finance, Economics, and Business, vol. 7, no. 6, pp. 241-254, 2020.

[7] Z. Mohtashami, A. Aghsami, and F. Jolai, "A green closed loop supply chain design using queuing system for reducing environmental impact and energy consumption," Journal of cleaner production, vol. 242, p. 118452, 2020.

[8] Q. Wang, J. Qu, B. Wang, P. Wang, and T. Yang, "Green technology innovation development in China in 1990-2015," Science of the Total Environment, vol. 696, 2019, doi: 10.1016/j.scitotenv.2019.134008.

[9] M. Ghodsvali, S. Krishnamurthy, and B. de Vries, "Review of transdisciplinary approaches to food-waterenergy nexus: A guide towards sustainable development," Environmental Science and Policy, vol. 101. pp. 266-278, 2019, doi: 10.1016/j.envsci.2019.09.003.

[10] J. C. Gill, J. Mankelow, and K. Mills, "The role of Earth and environmental science in addressing sustainable development priorities in Eastern Africa," Environmental Development, vol. 30, pp. 3-20, 2019, doi: 10.1016/j.envdev.2019.03.003.

[11] S. bashir, M. G. Khwaja, J. A. Turi, and H. Toheed, "Extension of planned behavioral theory to consumer behaviors in green hotel," Heliyon, vol. 5, no. 12, 2019, doi: 10.1016/j.heliyon.2019.e02974.

[12] D. I. Stern, M. S. Common, and E. B. Barbier, "Economic growth and environmental degradation: the environmental Kuznets curve and sustainable development," World development, vol. 24, no. 7, pp. 1151-1160, 1996.

[13] Q. Wang, J. Qu, B. Wang, P. Wang, and T. Yang, "Green technology innovation development in China in 1990-2015," Science of the Total Environment, vol. 696, p. 134008, 2019.

[14] A. Bjoern et al., "Review of life-cycle based methods for absolute environmental sustainability assessment and their applications," Environmental Research Letters, vol. 15, no. 8, p. 083001, 2020. 
[15] L. I. Syafii, A. Thoyib, U. Nimran, and Djumahir, "The Role of Corporate Culture and Employee Motivation as a Mediating Variable of Leadership Style Related with the Employee Performance (Studies in Perum Perhutani)," Procedia - Social and Behavioral Sciences, vol. 211, pp. 1142-1147, 2015, doi: 10.1016/j.sbspro.2015.11.152.

[16] M. Hogendorf, J. Oude Groeniger, J. M. Noordzij, M. A. Beenackers, and F. J. van Lenthe, "Longitudinal effects of urban green space on walking and cycling: A fixed effects analysis," Health and Place, vol. 61, 2020, doi: 10.1016/j.healthplace.2019.102264.

[17] I. Ajzen and P. Schmidt, Changing behaviour using the theory of planned behavior. Cambridge University Press: New York, NY, USA, 2020.

[18] K. Parajuly, C. Fitzpatrick, O. Muldoon, and R. Kuehr, "Behavioral change for the circular economy: A review with focus on electronic waste management in the EU," Resources, Conservation \& Recycling: $X$, vol. 6, p. $100035,2020$.

[19] M. A. Mancini, "Models of Change and Well-Being from Behavioral Health Disorders," in Integrated Behavioral Health Practice, Springer, 2021, pp. 59-84.

[20] A. Alkharabsheh, Z. A. Ahmad, and A. Kharabsheh, "Characteristics of Crisis and Decision Making Styles: The Mediating Role of Leadership Styles," Procedia Social and Behavioral Sciences, 2014, doi: 10.1016/j.sbspro.2014.03.678.

[21] C. N. Hadley, T. L. Pittinsky, S. A. Sommer, and W. Zhu, "Measuring the efficacy of leaders to assess information and make decisions in a crisis: The CLEAD scale," The Leadership Quarterly, vol. 22, no. 4, pp. 633-648, 2011.

[22] A. Alkharabsheh, Z. A. Ahmad, and A. Kharabsheh, "Characteristics of crisis and decision making styles: The mediating role of leadership styles," ProcediaSocial and Behavioral Sciences, vol. 129, pp. 282-288, 2014.

[23] F. Özer and C. Tinaztepe, "Effect of Strategic Leadership Styles on Firm Performance: A Study in a Turkish SME," Procedia - Social and Behavioral Sciences, vol. 150, pp. 778-784, 2014, doi: 10.1016/j.sbspro.2014.09.059.

[24] C. Dumitriu, I. C. Timofti, E. Nechita, and G. Dumitriu, "The Influence of the Locus of Control and Decisionmaking Capacity upon the Leadership Style," Procedia - Social and Behavioral Sciences, 2014, doi: 10.1016/j.sbspro.2014.05.086.

[25] E. G. Guba and Y. S. Lincoln, Effective evaluation: Improving the usefulness of evaluation results through responsive and naturalistic approaches. Jossey-Bass, 1981.

[26] G. Eysenbach and C. Köhler, "How do consumers search for and appraise health information on the world wide web? Qualitative study using focus groups, usability tests, and in-depth interviews," Bmj, vol. 324, no. 7337, pp. 573-577, 2002.

[27] J. M. Johnson, "In-depth interviewing," Handbook of interview research: Context and method, vol. 1, 2002.
[28] B. DiCicco-Bloom and B. F. Crabtree, "The qualitative research interview," Medical education, vol. 40, no. 4, pp. 314-321, 2006.

[29] K. J. Devers and R. M. Frankel, "Study design in qualitative research--2: Sampling and data collection strategies," Education for health, vol. 13, no. 2, p. 263, 2000.

[30] J. N. Lester, Y. Cho, and C. R. Lochmiller, "Learning to do qualitative data analysis: A starting point," Human Resource Development Review, vol. 19, no. 1, pp. 94106, 2020.

[31] C. Vindrola-Padros and G. A. Johnson, "Rapid techniques in qualitative research: A critical review of the literature," Qualitative Health Research, vol. 30, no. 10, pp. 1596-1604, 2020.

[32] B. Lobe, D. Morgan, and K. A. Hoffman, "Qualitative data collection in an era of social distancing," International Journal of Qualitative Methods, vol. 19, p. $1609406920937875,2020$.

Creative Commons Attribution License 4.0 (Attribution 4.0 International ,CM3 BY 4.0)

This article is published under the terms of the Creative Commons Attribution License 4.0

https://creativecommons.org/licenses/by/4.0/deed.e $\underline{\mathrm{n} U S}$ 
Table 1. Research Flow Matrix

\begin{tabular}{|c|c|c|c|c|c|c|}
\hline NO & $\begin{array}{c}\text { Formulation of } \\
\text { the problem }\end{array}$ & $\begin{array}{l}\text { Research } \\
\text { purposes }\end{array}$ & $\begin{array}{c}\text { Parameters / } \\
\text { variables }\end{array}$ & $\begin{array}{l}\text { Data collection } \\
\text { technique }\end{array}$ & Informant & $\begin{array}{c}\text { Type of } \\
\text { Data }\end{array}$ \\
\hline (1) & $(2)$ & (3) & $(4)$ & $(5)$ & $(6)$ & $(7)$ \\
\hline 1. & $\begin{array}{l}\text { What is the } \\
\text { condition of } \\
\text { sustainable } \\
\text { natural resource } \\
\text { management } \\
\text { and the } \\
\text { environment in } \\
\text { South } \\
\text { Kalimantan? }\end{array}$ & $\begin{array}{l}\text { Analyze the } \\
\text { condition of } \\
\text { sustainable natural } \\
\text { resource and } \\
\text { environmental } \\
\text { management in } \\
\text { South Kalimantan }\end{array}$ & $\begin{array}{ll}\text { - } & \text { Vision and } \\
& \text { mission } \\
\text { - } & \text { IKLH (IKA, } \\
& \text { IKU, IKTL) } \\
\text { - } & \text { RPJMD. - RTRW } \\
\text { - } & \text { Renstra - SDGs } \\
\text { - } & \text { Program - Lakip }\end{array}$ & $\begin{array}{l}\text { Document } \\
\text { Analysis }\end{array}$ & Researcher & Secondary \\
\hline 2. & $\begin{array}{l}\text { What are the } \\
\text { policies for } \\
\text { managing } \\
\text { natural } \\
\text { resources and } \\
\text { the environment } \\
\text { in a sustainable } \\
\text { manner in South } \\
\text { Kalimantan? }\end{array}$ & $\begin{array}{l}\text { Analyzing policies } \\
\text { for sustainable } \\
\text { natural resource } \\
\text { and environmental } \\
\text { management in } \\
\text { South Kalimantan }\end{array}$ & $\begin{array}{ll}\text { - } & \text { Environmental } \\
& \text { Policy (SDGs) } \\
\text { - } & \text { Budgeting / } \\
& \text { Budgeting } \\
& \text { policies } \\
\text { - } & \text { Quality Policy }\end{array}$ & $\begin{array}{l}\text { - Document } \\
\text { Analysis } \\
\text { - Observation }\end{array}$ & Researcher & $\begin{array}{l}\text { Primary } \\
\text { secondary }\end{array}$ \\
\hline 3. & $\begin{array}{l}\text { How is the } \\
\text { accessibility of } \\
\text { the community } \\
\text { in managing } \\
\text { natural } \\
\text { resources and } \\
\text { the environment } \\
\text { in a sustainable } \\
\text { manner in South } \\
\text { Kalimantan? }\end{array}$ & $\begin{array}{l}\text { Analyzing the } \\
\text { accessibility of the } \\
\text { community in } \\
\text { managing natural } \\
\text { resources and the } \\
\text { environment in a } \\
\text { sustainable manner } \\
\text { in South } \\
\text { Kalimantan }\end{array}$ & $\begin{array}{ll}\text { - } & \text { Community } \\
& \text { access } \\
\text { - } & \text { Society } \\
& \text { participation } \\
\text { - } & \text { Environmental } \\
& \text { Complaints } \\
& \text { Service }\end{array}$ & $\begin{array}{l}\text { - Observation } \\
\text { - Interview }\end{array}$ & $\begin{array}{l}\text { - Governor } \\
\text { - Mayor } \\
\text { - Regent } \\
\text { - Public figures } \\
\text { - NGOs, DPRD } \\
\text { - Practitioners of } \\
\text { PT }\end{array}$ & Primary \\
\hline 4. & $\begin{array}{l}\text { What is the } \\
\text { leadership role } \\
\text { in managing } \\
\text { natural } \\
\text { resources and } \\
\text { the environment } \\
\text { in a sustainable } \\
\text { manner in South } \\
\text { Kalimantan? }\end{array}$ & $\begin{array}{l}\text { Analyze the role of } \\
\text { leadership in the } \\
\text { management of } \\
\text { natural resources } \\
\text { and the } \\
\text { environment in a } \\
\text { sustainable manner } \\
\text { in South } \\
\text { Kalimantan }\end{array}$ & $\begin{array}{ll}\text { - } & \text { Understand } \\
\text { environmental } \\
\text { issues } \\
\text { - } \text { Response to } \\
\text { policy } \\
\text { - innovation } \\
\text { - } \text { Commitment } \\
\text { - Institution } \\
\text { - } \text { Management } \\
\text { function }\end{array}$ & - Interview & $\begin{array}{l}\text { - Governor } \\
\text { - Mayor } \\
\text { - Regent } \\
\text { - Public figures } \\
\text { - NGOs } \\
\text { - Practitioners of } \\
\text { PT }\end{array}$ & Primary \\
\hline 5. & $\begin{array}{l}\text { How is the } \\
\text { formulation of a } \\
\text { green leadership } \\
\text { model in the } \\
\text { management of } \\
\text { natural } \\
\text { resources and } \\
\text { the environment } \\
\text { in a sustainable } \\
\text { manner in South } \\
\text { Kalimantan? }\end{array}$ & $\begin{array}{l}\text { Formulate a green } \\
\text { leadership model } \\
\text { in the management } \\
\text { of natural } \\
\text { resources and the } \\
\text { environment in a } \\
\text { sustainable manner } \\
\text { in South } \\
\text { Kalimantan }\end{array}$ & $\begin{array}{l}\text { - The results of the } \\
\text { analysis of the } \\
\text { locus conditions } \\
\text { - The results of } \\
\text { policy analysis } \\
\text { - The results of the } \\
\text { accessibility } \\
\text { analysis } \\
\text { - The Results Of } \\
\text { The Analysis Of } \\
\text { The Role Of } \\
\text { Leadership }\end{array}$ & - Interview & $\begin{array}{l}\text { - Governor } \\
\text { - Mayor } \\
\text { - Regent } \\
\text { - Public figures } \\
\text { - NGOs } \\
\text { - Practitioners of } \\
\text { PT }\end{array}$ & Primary \\
\hline
\end{tabular}

